\title{
Seed Bank Modelling of Volunteer Oil Seed Rape: fRom Seeds Fate in The SoIl to Seedling Emergence ${ }^{1}$
}

\author{
Modelagem do Banco de Sementes de Canola: do Destino das Sementes no Solo à Emergência \\ das Plântulas
}

\author{
SOLTANI, E. ${ }^{2,3^{*}}$, SOLTANI, A. ${ }^{2}$, GALESHI, S. ${ }^{2}$, GHADERI-FAR, F. ${ }^{2}$, and ZEINALI, E. ${ }^{2}$
}

\begin{abstract}
Studies were conducted to estimate parameters and relationships associated with sub-processes in soil seed banks of oilseed rape in Gorgan, Iran. After one month of burial, seed viability decreased to $39 \%$, with a slope of $2.03 \%$ per day, and subsequently decreased with a lower slope of 0.01 until 365 days following burial in the soil. Germinability remained at its highest value in autumn and winter and decreased from spring to the last month of summer. Non-dormant seeds of volunteer oilseed rape did not germinate at temperatures lower than $3.8^{\circ} \mathrm{C}$ and a water potential of $-1.4 \mathrm{MPa}{ }^{\circ} \mathrm{d}$. The hydrothermal values were 36.2 and $42.9 \mathrm{MPa}{ }^{\circ} \mathrm{d}$ for sub- and supra-optimal temperatures, respectively. Quantification of seed emergence as influenced by burial depth was performed satisfactorily $\left(R^{2}=0.98\right.$ and RMSE $\left.=5.03\right)$. The parameters and relationships estimated here can be used for modelling soil seed bank dynamics or establishing a new model for the environment.
\end{abstract}

Keywords: life cycle, seed survival, dormancy cycle, hydrothermal time model, burial depth.

RESUMO - Estudos foram realizados para estimar os parâmetros e as relações ligados a subprocessos em bancos de sementes de canola no solo, em Gorgan, Iran. Após um mês de enterrio, a viabilidade das sementes diminuiu para 39\%, com inclinação de 2,03\% ao dia; posteriormente, diminuiu com menor inclinação: de 0,01 até 365 dias após o enterrio no solo. A germinação manteve-se em seu maior valor no outono e inverno, reduzindo da primavera ao último mês do verão. Sementes de canola não dormentes não germinaram em temperaturas abaixo de $3,8{ }^{\circ} \mathrm{C}$ e potencial hídrico abaixo de 1,4 $\mathrm{Mpa}{ }^{\circ} \mathrm{d}$. Os valores hidrotermais foram de 36,2 e 42, $9 \mathrm{Mpa}{ }^{\circ} \mathrm{d}$ para temperaturas sub e supraótima, respectivamente. A quantificação da emergência das sementes sob influência da profundidade de enterrio foi delineada de forma satisfatória $\left(R^{2}=0,98\right.$ e $\left.R M S E=5,03\right)$. Os parâmetros e as relações estimadas neste estudo podem serutilizados em modelagens do banco de sementes do solo ou para estabelecerum novo modelo para o meio ambiente.

Palavras-chave: ciclo de vida, sobrevivência da semente, ciclo de dormência, modelo hidrotermal temporal, profundidade de enterrio.

\section{INTRODUCTION}

An undesirable characteristic of oilseed rape (Brassica napus) cultivars is that dehiscent pods result in frequent seed shattering following maturity and desiccation, and thus, the shattered seeds will enlarge the soil seed bank of volunteer oilseed rape.
Volunteer oilseed rape is known as a weed in crop production fields, such as those of winter wheat (Gruber et al., 2008; Colbach et al., 2008; Gruber et al., 2010). Gulden et al. (2003) indicated that the average seed bank additions of oilseed rape equalled approximately $100 \mathrm{~kg} \mathrm{ha}^{-1}$, or 3,000 viable seeds $\mathrm{m}^{-2}$. This value is 20 times greater than the normal

Recebido para publicação em 16.11.2012 e aprovado em 20.2.2013.

2 Department of Agronomy, Gorgan University of Agricultural Sciences and Natural Resources, Gorgan 49138-15739, Iran; ${ }^{3}$ Department of Agronomy and Plant Breeding, Aboureihan Campus University of Tehran, Pakdasht, Tehran, Iran, P.O.Box: 11365/7117*Corresponding Author: Mobile: +98-911-2782644, <elias.soltani@yahoo.com>. 
seeding rate of 4 to $5 \mathrm{~kg} \mathrm{ha}^{-1}$ for the crop, which can easily lead to the establishment of volunteer oilseed rape populations (Lawson \& Friesen, 2006). Simard et al. (2002) reported that in Europe, oilseed rape seeds persist in the soil for at least 5 years, and volunteer plants were observed in the field up to 10 years after production (Knott, 1993; Lutman \& LópezGranados, 1998). This duration was up to 4 years for volunteer plants in western Canada (Thomas \& Leeson, 1999).

Models can be used to determine how the effects of oilseed rape seed banks on cropping systems can be managed. For example, models are an essential tool to test and evaluate a wide range of possible tillage strategies interacting with different rotations for the management of oilseed rape volunteers (Colbach et al., 2008). Various models have been developed to predict the persistence (Begg et al., 2006; Middelhoff et al., 2011), seed bank evolution and emergence (Colbach et al., 2008), fecundity and gene flow (Colbach et al., 2001a ,b; Gruber \& Claupein, 2007) and seed bank dynamics (Gonzalez-Andujar \& Fernandez-Quintanilla, 2004; Pekrun et al., 2005) of volunteer oilseed rape. Colbach \& Debaeke (1998) showed the need to use mechanistic models instead of empirical models. In mechanistic models, the life-cycle is split into sub-processes to account for the biological and physical effects of cropping systems interacting with the biological (e.g., structure of the crop) and physical environment (e.g., soil structure) of weeds (Colbach \& Debaeke, 1998; Colbach et. al., 2007). These models cannot be extrapolated for use in conditions and cropping systems other than those where they had been developed (Colbach et al., 2007). Therefore, it is necessary to measure a series of major seed bank lifecycle variables for each environmental condition. Here, we considered three subprocesses to quantify the soil seed bank of oilseed rape.

(1) Germinability cycle: An important part of improving weed control practices is learning how to best manipulate seed dormancy, which controls weed-seed behaviour in arable soil (Pekrun et al., 1997a, b; Chuah et al., 2004; Gulden et al. 2004; Batlla \& BenechArnold, 2007). Benech-Arnold et al. (2000) suggested that certain environmental factors (temperature and water potential) modify the dormancy level of seeds, whereas other factors (light, nitrates, and temperature fluctuation) act to terminate dormancy. It has been indicated that secondary dormancy in oilseed rape is influenced by darkness in combination with osmotic stress and hypoxia (Pekrun et al., 1997b; Momoh et al., 2002). Gulden et al. (2004) also showed that the role of temperature was approximately threefold more important for seed dormancy development than osmotic potential. Hypoxia may also induce secondary dormancy in oilseed rape seed to a lesser degree (Pekrun et al., 1997b; Momoh et al., 2002). The most accurate way to determine the viability and germinability of seeds in the soil is to bury them, wait for various periods of time, dig up samples, and check for viability and germinability (Baskin \& Baskin, 2006). Researchers are using this method to evaluate viability and determine dormancy/nondormancy cycles (Pekrun et al., 1997a; Masin et al., 2006; Franke et al., 2007; Colbach et al., 2008). Reports on the dormancy and germinability cycle of oilseed rape have provided contradictory results: Pekrun et al. (1997a) found no clear indication of oilseed rape displaying a dormancy cycle, whereas Colbach et al. (2008) demonstrated during the evaluation of their model that the secondary dormancy cycle of oilseed rape improved model predictions. These results demonstrate the need to conduct further studies focusing on the possibility of a germinability cycle in oilseed rape.

(2) Germination modelling: Non-dormant seed germination rates and percentages are dependent on temperature and water potential (Gardarin et al., 2010b, 2011). A variety of mathematical functions have been used to describe the relationship between germination rate and temperature (Soltani et al., 2006, 2008). Marshall \& Squire (1996) showed that base temperature $\left(\mathrm{T}_{\mathrm{b}}\right)$ was approximately $3{ }^{\circ} \mathrm{C}$ for oilseed rape germination. Squire (1999) indicated that early percentiles, up to the $50^{\text {th }}$ percentile in two oilseed rape cultivars (Rocket $\&$ Martina) and up to the $20^{\text {th }}$ in a third one (Comet), responded to temperature similarly during all sowings, such that the inverse time to the emergence of a percentile (emergence rate) increased exponentially with temperature above an intercept of $-1{ }^{\circ} \mathrm{C}$. The 
advantage of these functions is that they include parameters that are meaningful from a biological point of view, such as cardinal temperatures and maximum inherent rates of germination or emergence. Thermal time (TT) and hydrotime (HT) models have also been used to describe the effect of temperature and water potential on seed germination and dormancy (Bradford, 2002). Additionally, temperature and water potential have been successfully combined into a hydrothermal time model (HTT) (Gummerson, 1986; Bradford, 1995, 2002). Using this model base values $\left(\psi_{\mathrm{b}}\right.$ and $\mathrm{T}_{\mathrm{b}}$ ), TT, HT and HTT would be calculable, which can be used in seed bank population dynamic models (Colbach et al., 2006; Sester et al., 2007). There is no information available regarding HTT models of oilseed rape.

(3) Emergence: Burial depth can influence weed seedling emergence by affecting the availability of soil moisture, $\mathrm{O}_{2}$ and light (Benvenuti, 2007). Germination also decreases with seed depth, even if moisture, $\mathrm{O}_{2}$ and light are the same (Colbach et al., 2006; Sester et al., 2007; Gardarin et al., 2010a). A failure to emerge can result from insufficient germination or from pre-emergent mortality. As heterotrophic seedling growth in the soil depends on seed reserves, buried seeds in deeper soil layers will require more seed reserves and cannot emerge from a threshold burial depth. Gruber et al. (2010) studied oilseed rape emergence as affected by sowing depth in a pot experiment, but they did not quantify the relationship between these parameters. The effect of sowing depth on oilseed rape emergence has been satisfactorily modelled in GENESYS (Colbach et al., 2008). However, it is necessary to examine the effect of burial depth on oilseed rape emergence for possible differences between cultivars and environmental conditions.

Information regarding soil seed banks of oilseed rape volunteers is scarce, as indicated above. Therefore, the aims of this research were to split the life-cycle of the oilseed rape volunteer seed bank into three sub-processes: (1) to investigate the seasonal dormancy/ non-dormancy cycle of buried seeds, (2) to model seed germination on the response to temperature and water potential and (3) to quantify the effect of burial depth on seedling emergence.

\section{MATERIALS AND METHODS}

\section{Seed longevity and germinability - study 1}

Seeds were collected from oilseed rape (cv. Hayola 401) fields around Gorgan throughout May 2009. The seeds were buried at the Research Farm of GUASNR or stored in the laboratory $\left(20 \pm 5{ }^{\circ} \mathrm{C}, 75 \% \mathrm{RH}\right.$, dark) on 23 Sep 2009. One thousand oilseed rape seeds and $10 \mathrm{~g}$ of incorporated soil (dry silty clay loam) were placed in nylon bags of $4 \times 8 \mathrm{~cm}$ with a pore size of $10 \mu \mathrm{m}$. A total of 12 nylon bags were used, and one of them was exhumed each month. Each nylon bag was placed in a nylon basket to protect seeds from predation. Finally, the nylon baskets were buried at a soil depth of $30 \mathrm{~cm}$. After burial, bags with seeds were exhumed monthly for the duration of the experiment. After exhumation, the sample (containing soil and seeds) was placed on a screen with two mesh sizes (1 and $2 \mathrm{~mm}$ diameter) and washed with water. The oilseed rape seeds isolated through direct seed extraction were tested for viability. Within $24 \mathrm{~h}$ after exhumation, germination tests were initiated. Germination tests were conducted in an incubator at $20{ }^{\circ} \mathrm{C}$ under two conditions: darkness and light. Seeds stored in the lab were also evaluated in germination tests under the same conditions in the dark. For seeds stored both in the lab and at the farm, three replications were conducted, each consisting of 50 seeds for each treatment in which seeds were germinated. Seeds were placed on moist filter paper (Whatman No. 40, $15 \mathrm{~cm}$ diameter) in Petri dishes. The dishes were moistened with $10 \mathrm{~mL}$ of water to condition the seeds. Dark conditions were implemented by wrapping aluminium foil around each Petri dish. After 14 days, the germinated seeds were counted, and all remaining seeds were evaluated for dormancy by probing the seeds with fine-tipped forceps; obviously dead seeds were removed, and seeds appearing firm were considered as viable (apparently viable seeds).

Viability (\%) and germinability (\%) were calculated using the following equations (Masin et al., 2006):

$$
\begin{aligned}
\text { Viability }(\%)= & \underset{\text { seeds } / \text { buried seeds }) \times 100 \quad(\text { eq. } 1)}{(\text { apparently viable }}
\end{aligned}
$$


Germinability $(\%)=($ germinated seeds $/$ pparently viable seeds) $\times 100$

(eq. 2)

The percentage of germinated seeds determined in the germination tests was considered as 'germinated seeds' here.

Volunteer oilseed rape longevity was quantified using the percentage of viable seeds. Viability over time was described using a non-linear regression, as follows:

$$
\begin{array}{ll}
\operatorname{Viability}(\%)=y_{\min }-b_{1}\left(x-x_{0}\right) & \text { if } \mathrm{x}<\mathrm{x}_{\mathrm{o}} \\
\operatorname{Viability}(\%)=y_{\min }-b_{2}\left(x_{0}-x\right) & \text { if } \mathrm{x} \geq \mathrm{x}_{\mathrm{o}}
\end{array}
$$

where $\mathrm{x}$ is the time (day) after burial, and $b_{1}$, $b_{2}$ (percent per day) and $\mathrm{x}_{0}$ (day) are model parameters showing the slopes and the turning point, respectively, in a non-linear regression. Viability decreased with two slopes that can be separated by a turning point during burial.

Germinability was quantified following the equation below (Colbach et al., 2008):

$$
\text { Germinability }(\%)=\cos (3 ð \cdot d a y / 365+c) \cdot(1-b)+b
$$

These equations were implemented using SAS (SAS, 2000).

\section{Seed germination modelling - study 2}

Seeds were collected from oilseed rape (cv. Hayola 401) fields around Gorgan during May 2009. Four replicates were conducted, each consisting of 50 seeds, in which seeds were germinated at constant temperatures ranging from 5 to $35{ }^{\circ} \mathrm{C}$ with $5{ }^{\circ} \mathrm{C}$ increments in 7 incubators under dark conditions. There were five water potentials, $0,-0.2,-0.4,-0.6$ and $0.8 \mathrm{MPa}^{(1)}$, in each temperature. Water potentials were maintained with solutions of polyethylene glycol 8000 . Before seed placement, filter paper was soaked in Petri dishes containing an osmotic solution for the desired water potential for $24 \mathrm{~h}$. Seeds were observed twice daily and considered germinated

(1) Megapascal. when the radicle was approximately $\geq 2 \mathrm{~mm}$ long. Estimates of the time taken for cumulative germination to reach $50 \%$ of its maximum in each replicate (D50) were interpolated from the germination progress curve versus time. Germination rate (R50 1/ h) was then calculated according to Ellis et al., (1986) and Soltani et al., (2001, 2002):

$$
\mathrm{R} 50=1 / \mathrm{D} 50
$$

To quantify the response of the germination rate to temperature and to determine cardinal temperatures for germination, the following model was used:

$$
R 50=f(T) R_{\max }
$$

where $f(T)$ is a temperature $\left({ }^{\circ} \mathrm{C}\right)$ function, and $R_{\max }$ is the inherent maximum rate of germination at the optimal temperature. Thus, $1 / R_{\max }$ indicates the minimum number of hours required for germination at the optimal temperature. Segmented functions $(\mathrm{f}(\mathrm{T}))$ were tested (Ritchie \& NeSmith 1991; Soltani et al., 2006; Soltani et al., 2008):

$$
\begin{aligned}
& f(T)=\left(T-T_{b}\right) /\left(T_{o}-T_{b}\right) \quad \text { if } \quad T_{b}<T d " T_{o} \\
& f(T)=\left(T_{c}-T\right) /\left(T_{c}-T_{o}\right) \quad \text { if } \quad T_{o}<T<T_{c} \\
& f(T)=0 \quad \text { if } \quad T d " T_{b} \text { or } T \geq T_{c}
\end{aligned}
$$

where $T$ is the temperature $\left({ }^{\circ} \mathrm{C}\right), T_{b}$ is the base temperature, $T_{o}$ is the optimum temperature and $T_{c}$ is the ceiling temperature. The parameters were estimated by the least squares method using the non-linear (NLIN) regression $\left(R_{50}\right.$ as $y$ and $T$ as $\left.x\right)$ procedure in SAS (SAS, 2000).

A thermal time $\left(\mathrm{TT}^{\circ} \mathrm{C}\right.$ day) model was fitted using the following equation at sub- (8) and supra- (9) optimal temperatures (Bradford, 2002):

$$
\begin{aligned}
& T T_{\text {sub }}=\left(T-T_{b}\right) t_{g} \\
& T T_{\text {supra }}=\left(T_{c}-T\right) t_{g}
\end{aligned}
$$

where $T$ is the actual temperature, $T_{b}$ and $T_{c}$ are the base and ceiling temperatures for germination, and $t_{g}$ is the time from water addition to germination $(g)$. 
The following equation was used for the hydrotime model (Gummerson, 1986; Bradford, 1990, 2002):

$$
H T=\left(\psi-\psi_{b(g)}\right) t_{g}
$$

where $H T$ is the hydrotime constant (MPaday) ${ }^{(2)}, \psi$ is the actual seed water potential $(\mathrm{MPa})$, $\psi_{b}(g)$ is the base or threshold water potential (MPa) defined for a specific germination fraction (g) and $t_{g}$ is the time (day) to radicle emergence of fraction $\mathrm{g}$ of the seed population.

When the sub-optimal temperature and $\psi$ are both varied, germination rates can be described based on a combined hydrothermal time scale according to the hydrothermal time model (Gummerson, 1986; Bradford, 1995, 2002), which can be derived by combining equations (8) and (10):

$$
\mathrm{HTT}=\left(\psi-\psi_{b(g)}\right)\left(T T_{b}\right) t_{g}
$$

where HHT is the hydrothermal time constant ( $\mathrm{MPa}{ }^{\circ}$ day), i.e., a combination of accumulated thermal time at temperatures above $T_{b}$ and accumulated hydrotime at $\psi$ levels above $\psi_{b}(g)$.

For the supra-optimal range of $T$, equation (11) is modified as follows (Alvarado, 2000; Bradford, 2002; Rowse \& Finch-Savage, 2003):

$$
H T T=\left\{\psi-\left[\psi_{b(g) o}+\left[k_{T} \cdot\left(T-T_{o}\right)\right]\right]\right\}\left(T_{o}-T_{b}\right) \cdot t_{g}
$$

where $k_{T}$ is a constant (the slope of $\psi_{b(g)}$ versus $T$ line when $T>T_{0}$ ), and $\psi_{b(g) o}$ represents the values of the $\psi_{\mathrm{b}(\mathrm{g})}$ distribution at $\mathrm{T}_{\mathrm{o}}$.

All model fitting was undertaken in SAS (SAS, 2000) using a non-linear fitting procedure.

\section{Seedling emergence - Study 3}

The effect of burial depth on seedling emergence was studied at the greenhouse of GUASNR. Fifteen oilseed rape seeds, provided as in studies 1 and 2 , were sown in plastic pots $(15 \mathrm{~cm}$ in diameter and $40 \mathrm{~cm}$ deep) filled

(2) Megapascal day with a silty clay loam (28\% clay, $62 \%$ silt, $10 \%$ sand) soil. The soil was obtained by excavations from a depth of over $0.5 \mathrm{~m}$ to avoid the presence of preexisting seeds capable of invalidating the real experimental data on emergence rates. Additionally, the farm where the soil was collected had never cultivated under oilseed rape. The pots were filled gravimetrically with the soil and packed with uniform strength to avoid differential resistance to seedling emergence. The seeding depths tested were $1,2,3,4,5,6,8,10,12,15,20$ and $30 \mathrm{~cm}$. This study was performed under a completely randomised design with four replicates for each seeding depth. The experiments began on 1 ㅇ Jan. 2010, and the mean temperature during the experiments was approximately $10{ }^{\circ} \mathrm{C}$. The pots were observed daily for 45 days. Emerged seedlings were counted when a cotyledon appeared, and they were then removed. After 45 days, the soils in the pots were examined for intact seeds by sieving the soil. The seeds remaining in the soil were treated using $2000 \mathrm{ppm}$ gibberellic acid (GA3) to break seed dormancy. Thereafter, germination tests were performed in an incubator with a temperature of $20^{\circ} \mathrm{C}$ in the dark. By using this method, dormant seeds were separated from dead seeds.

Estimates of the time taken for cumulative emergence to reach $50 \%$ of its maximum for each replicate (D50) were interpolated from the emergence progress curve versus time, as described in equation (5).

The effect of burial depth on the seedling emergence of volunteer oilseed rape was quantified as follows:

$$
\begin{aligned}
& y=y_{\max } \quad \text { if } x<x_{o} ; \\
& y=y_{\max }\left(\exp \left(-b\left(x-x_{o}\right)\right)\right) \quad \text { if } x \geq x_{o}
\end{aligned}
$$

where $\mathrm{x}$ and $\mathrm{y}$ are burial depth and seedling emergence, respectively, and $\mathrm{b}$ and $\mathrm{x}_{0}$ are model parameters showing the slope and the turning point in a non-linear regression, respectively, conducted in SAS (SAS, 2000).

The relationship between seedling emergence rate and burial depth was described using a polynomial model. 


\section{RESULTS AND DISCUSSION}

\section{Seed longevity and germinability}

The initial germination percentage of buried seeds (initial germinability) was $94 \pm 1.2 \%$, and seed viability was $100 \%$. After one month of burial, seed viability decreased to $39 \%$ with a slope of $2.03 \%$ per day and subsequently decreased with a lower slope of 0.01 until 365 days after burial in the soil (Figure 1). There were no replications performed for the buried bags, but the model provided a good description of the changes of viability over time $\left(R^{2}=0.99\right)$. Examination of the seeds showed that $60 \%$ of the seeds in the nylon bags exhibited pre-emergent growth after one month of burial. These seedlings were not able to reach the soil surface because of mortality resulting from insufficient shoot length. Therefore, the main reason for decreased seed viability was fatal germination in the soil.

Seed germinability in the laboratory was between 90 and $97 \%$, and there were no significant differences over time (Figure 2A). Germinability was reduced to 50 and $8 \%$ under light and dark conditions, respectively, after one month of burial (Figure 2A), showing secondary dormancy. There was a cyclical change in germinability over one year after burial (Figure 2B). Germinability remained at the highest level in autumn and winter: 96 to $100 \%$ germination in light and 68 to $100 \%$ germination in dark. Germinability decreased from spring to the last month of summer: from

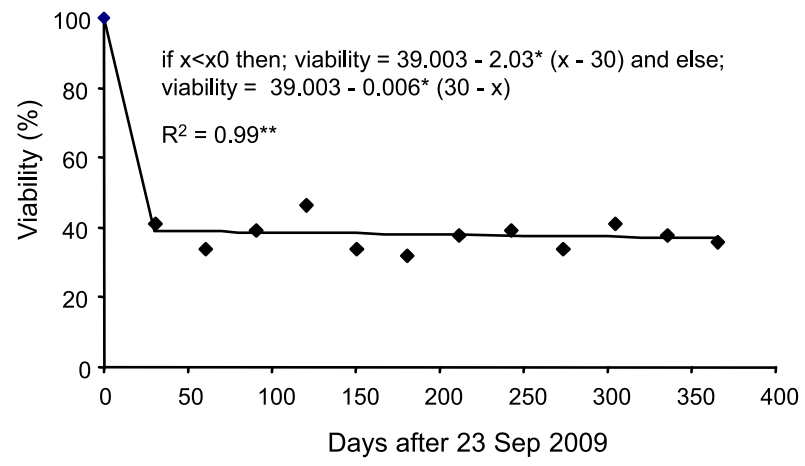

Figure 1 - Seed viability of oilseed rape after burial at $30 \mathrm{~cm}$ depth of soil in Gorgan. Seeds were buried on 23 Sep 2009.
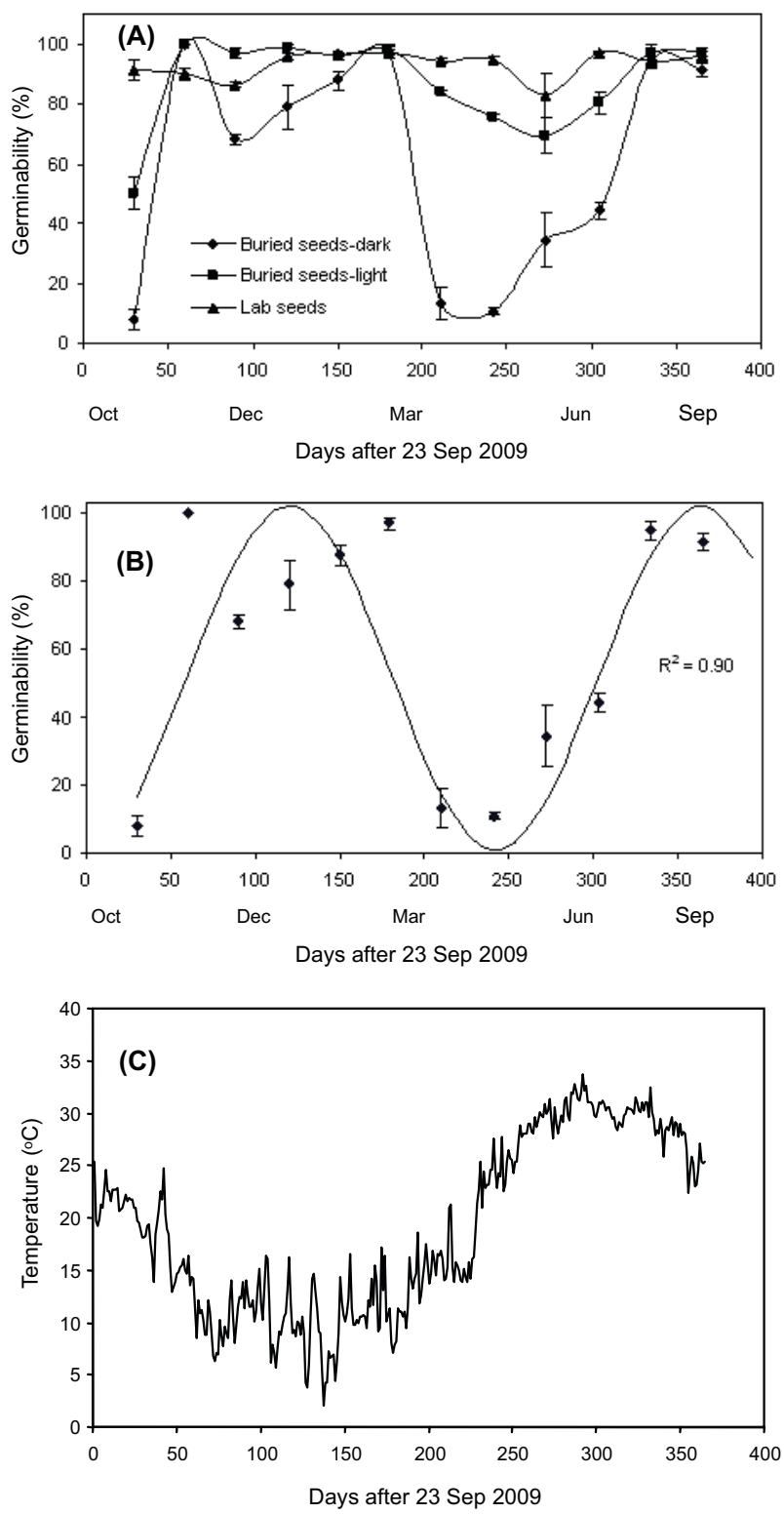

Figure 2 - Seasonal germinability of volunteer oilseed rape seeds after burial at 30-cm depth of soil (A). Seeds were buried on 23 Sep 2009. Model fitted to data from the germination test in dark (B). Mean daily air temperature on 23 Sep 2009 (C).

69 to $84 \%$ for germination in light and 11 to $44 \%$ for germination in dark (Figure 2A, B). During the last two months of burial, germinability increased again to the highest level (Figure 2A, B). The effect of light on seed germinability was significant. Induced dormancy was eliminated by germination in light, especially in seeds exhumed in the first 
month of burial and in summer (Figure 2A). A cyclical change in germinability was observed for the seeds under dark conditions over the year (Figure 2B). The model seems to fit the germinability changes $\left(R^{2}=0.90\right)$ satisfactorily and demonstrates the higher germinability of oilseed rape associated with the particular behaviour related to cyclical germination. The values for parameters $b$ and $c$ were 12.81 and 76.14, respectively. (Figure 2B, C) indicate the interaction of dormancy level and environmental factors. Warmer temperatures led to seed dormancy, and light was required for seed germination.

Similar results were reported by Gulden et al. (2004), but they did not investigate modelling of the germinability cycle in their study. Pekrun et al. (1997a) indicated that the germination of volunteer oilseed rape is mainly affected by light and temperature changes. Pekrun et al. (1997a) reported that there is no clear indication of oilseed rape displaying a dormancy cycle. However, Schlink (1994) observed a secondary dormancy cycle for oilseed rape, and Colbach et al. (2008) demonstrated during evaluation of their model that including the secondary dormancy cycle of oilseed rape improved model predictions. These results were similar to the ones presented in this study. Therefore, it appears that there is a dormancy/non-dormancy cycle dependent on burial depth and light conditions in the germination tests. Non-deep physiological dormancy (PD) is very common in buried weed seeds, and many of these species exhibit annual dormancy cycles in response to seasonal temperature changes (Baskin \& Baskin, 2006).

\section{Seed germination modelling}

The germination rate and final germination percentage of volunteer oilseed rape were severely affected by reduced water potential (Figure 3; Table 1). Estimates of cardinal temperatures and $R_{\max }$ are provided (Table 1); the estimates of $\mathrm{T}_{\mathrm{b}}$ ranged from 2.7 to $6.7^{\circ} \mathrm{C}$; $\mathrm{T}_{\text {。 }}$ varied between 20.6 and $27^{\circ} \mathrm{C}$; and the range of $\mathrm{T}_{c}$ was between 33.3 and $42{ }^{\circ} \mathrm{C}$. The median thermal time to germination $\left(\mathrm{TT}_{(50)}\right)$ increased from $29.5{ }^{\circ} \mathrm{C} \mathrm{d}^{-1}(\psi=0 \mathrm{MPa})$ to $57.9{ }^{\circ} \mathrm{C} \mathrm{d}^{-1}$ $(\psi=-0.8 \mathrm{MPa})$ at lower $\psi$ and sub-optimal temperatures (Table 1). Under supra-optimal temperatures $\mathrm{TT}_{(50)}$ ranged between 16 and $22{ }^{\circ} \mathrm{C} \mathrm{d}^{-1}$. The $\mathrm{R}^{2}$ values ranged from 0.91 to 0.97 in sub-optimal temperatures, and these values for supra-optimal temperatures were 0.98 to 0.99 . The $\mathrm{R}^{2}$ values showed a good fitness of the thermal time model under both sub- and supra-optimal temperatures.

The cumulative germination percentage and fitted hydrotime model for each temperature are shown in Figure 4. The predicted germination time courses at the various $\psi$ and temperature values generally fitted well with the observed germination data, with $\mathrm{R}^{2}$ values between 0.98 and 0.99 (Table 2). The estimated values of $\psi_{b(5)}, \sigma_{\psi b}$ and $\mathrm{HT}_{(50)}$ differed under different germination temperatures (Table 2). The lowest $\psi_{b(5))}$ and highest $\mathrm{HT}_{(50)}$ were observed at $5{ }^{\circ} \mathrm{C} . \psi_{\mathrm{b}(50)}$ increased from -3.1 MPa to - $0.76 \mathrm{MPa}$ with an increase in the germination temperature from 5 to $35{ }^{\circ} \mathrm{C}$. $\mathrm{HT}_{(50)}$ decreased from $37.3 \mathrm{MPa}{ }^{\circ} \mathrm{d}$ (at $5{ }^{\circ} \mathrm{C}$ ) to $1.3 \mathrm{MPa}{ }^{\circ} \mathrm{d}\left(\right.$ at $\left.30{ }^{\circ} \mathrm{C}\right)$ with an increase of $35^{\circ} \mathrm{C}\left(2.2 \mathrm{MPa}{ }^{\circ}\right.$ day $)$.

HTT parameters under sub- and supraoptimal temperatures are indicated in Table 3. The $R^{2}$ values were 0.94 and 0.96 for sub- and supra-optimal temperatures, which is indicative that the model generally accounted for a large part of the variation at a wide range of temperatures. HTT $_{(50)}$ under suboptimal temperatures was lower than under supra-optimal temperatures (Table 3).

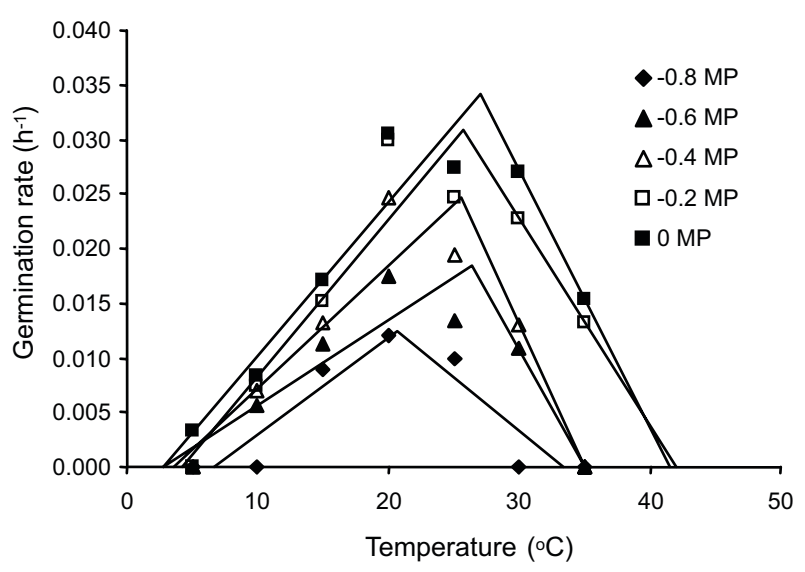

Figure 3 - Effect of temperature and water potential on germination rate (per $\mathrm{h}$ ). The lines show segmented function used to describe the response of germination rate to temperature in the range of water potentials. 


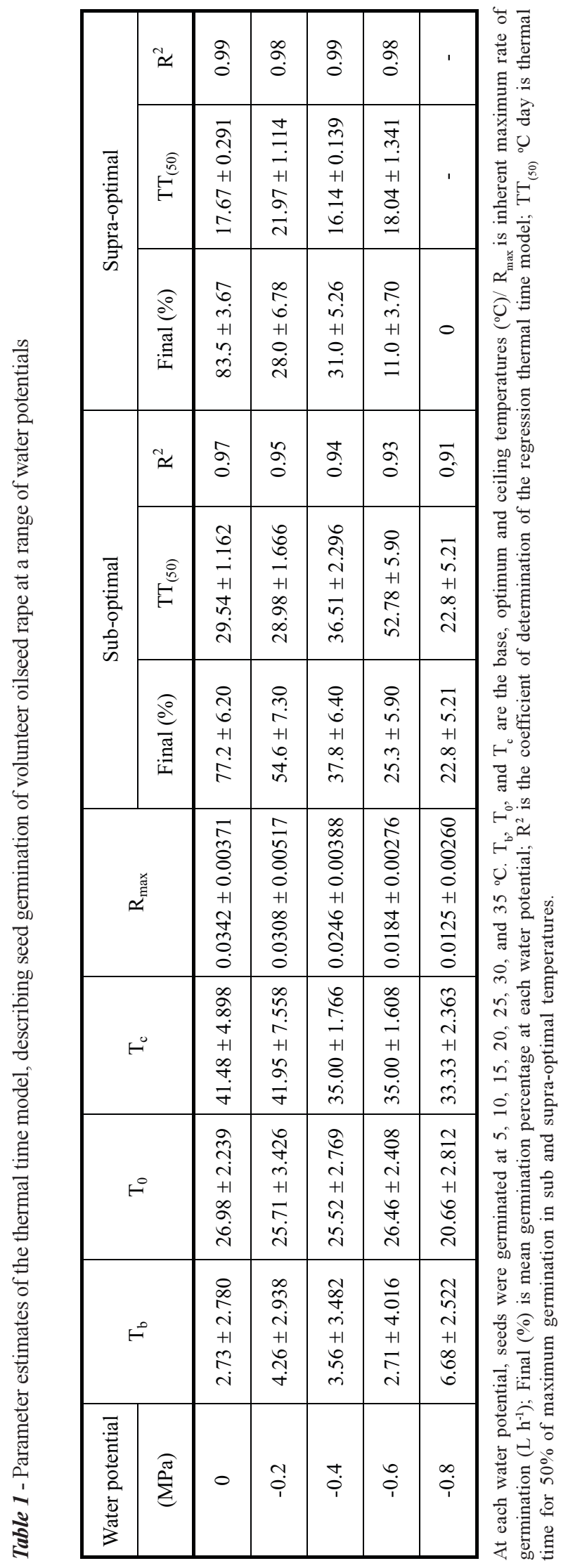

The hydrothermal value and base value of the temperature and water potential are needed to model seed bank dynamics and the emergence of weed species (Colbach et al., 2006; Sester et al., 2007). Non-dormant seeds of volunteer oilseed rape did not germinate at a lower temperature of $3.8^{\circ} \mathrm{C}$ and a water potential of $-1.4 \mathrm{MPa}{ }^{\circ} \mathrm{d}$. This result has been reported by Marshall and Squire (1996) for base temperature, but we could not find any reports on the base water potential of oilseed rape. The hydrothermal values were 36.2 and $42.9 \mathrm{MPa}{ }^{\circ} \mathrm{d}$ for sub- and supra-optimal temperatures. The mathematical models based on characterising the variation that occurs in germination times among individual seeds in a population can describe and quantify the effects of temperature and water potential on weed seed germination (Bradford, 2002). There are many reports using HTT models to predict weed seed germination or emergence (Kebreab \& Murdoch, 2000; Masin, et al., 2005; Bair et al., 2006; Martinson et al., 2007; Schutte et al., 2008), but there was no information available on HTT parameters for volunteer oilseed rape seed germination.

\section{Seedling emergence}

The seedling emergence percentage of volunteer oilseed rape was described well, as indicated (Figure 5A). The $\mathrm{R}^{2}$ and RMSE values for the model were 0.98 and 5.03 , respectively. Seedling emergence showed no change from a burial depth of $1 \mathrm{~cm}$ to $2.9 \mathrm{~cm}$ exhibiting a value of $98.4 \%$, but burial in deeper layers of soil from $2.9 \mathrm{~cm}$ to $10 \mathrm{~cm}$ led to a decrease in the seedling emergence percentage, as described by the model (Figure 5a). Seeds buried at a depth of $10 \mathrm{~cm}$ never emerged, and the seedling emergence of seeds buried at $8 \mathrm{~cm}$ was $15 \%$. The seedling emergence rate was satisfactorily described by a polynomial model $\left(R^{2}=0.98\right)$ (Figure 5B). According to this relationship, seeds of volunteer oilseed rape buried at soil depths of $1,3,5$ and $8 \mathrm{~cm}$ would emerge approximately 10.6, 13.1, 13.3 and 15.4 days after burial, respectively.

Depending on where the seeds were located in the soil profile, the dormancy level changed from $0 \%$ (from upper layers to $8 \mathrm{~cm}$ ) to approximately $40 \%$ (at soil depths of 20 and $30 \mathrm{~cm}$ ). There were ungerminated 

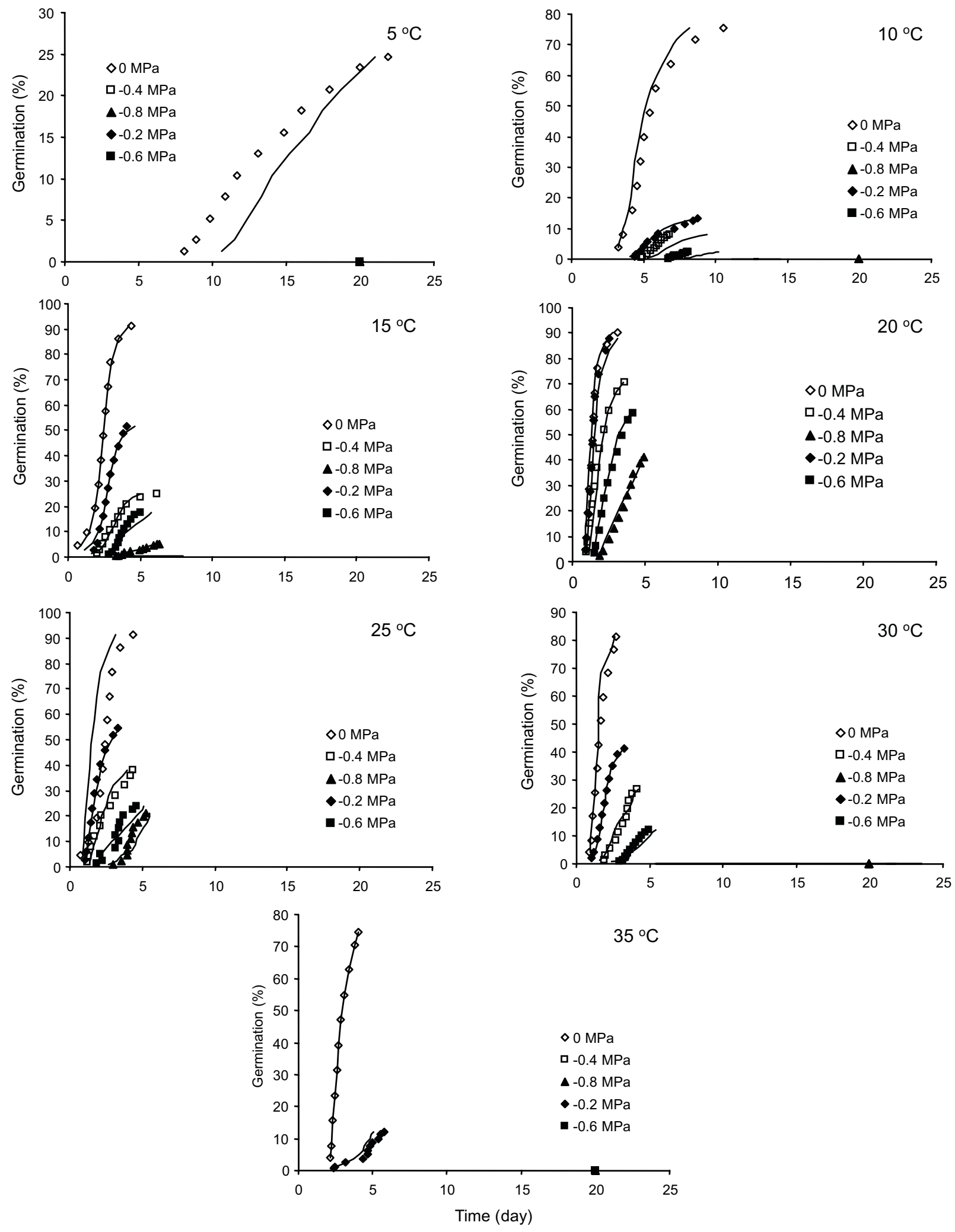

Figure 4 - Germination time courses for oilseed rape seeds germinated at a range of water potentials and at 5, 10, 15, 20, 25, 30 and $35^{\circ} \mathrm{C}$. The symbols indicate the interpolation of observed germination data and the lines indicate the germination time courses predicted by the hydrotime model, based on parameter estimates in Table 2. 
Table 2 - Parameter estimates of the hydrotime model at seven germination temperatures describing seed germination of volunteer oilseed rape at a range of water potentials. $\psi_{\mathrm{b}(50)}$ is the median base water potential; $\sigma_{\psi \mathrm{b}}$ is the standard deviation in base water potential; $\mathrm{HT}_{(50)}$ is the hydrotime constant; $\mathrm{R}^{2}$ is the coefficient of determination of the regression hydrotime model; Final (\%) is the mean germination percentage at each temperature

\begin{tabular}{|c|c|c|c|c|c|}
\hline Temperature $\left({ }^{\circ} \mathrm{C}\right)$ & $\psi_{\mathrm{b}(50)}$ & $\sigma_{\psi \mathrm{b}}$ & $\mathrm{HT}_{(50)}$ & $\mathrm{R}^{2}$ & Final $(\%)$ \\
\hline 5 & -3.11 & 2.56 & $37.31 \pm 21.543$ & 0.98 & $5.20 \pm 5.200$ \\
\hline 10 & -1.50 & 0.59 & $5.85 \pm 1.436$ & 0.98 & $20.90 \pm 14.850$ \\
\hline 15 & -1.64 & 0.40 & $4.05 \pm 0.068$ & 0.99 & $40.10 \pm 16.116$ \\
\hline 20 & -1.42 & 0.19 & $1.68 \pm 0.230$ & 0.99 & $73.33 \pm 9.679$ \\
\hline 25 & -1.30 & 0.23 & $1.80 \pm 0.118$ & 0.99 & $46.80 \pm 12.398$ \\
\hline 30 & -0.97 & 0.11 & $1.35 \pm 0.129$ & 0.99 & $34.53 \pm 15.340$ \\
\hline 35 & -0.76 & 0.46 & $2.22 \pm 0.673$ & 0.98 & $18.20 \pm 15.268$ \\
\hline
\end{tabular}
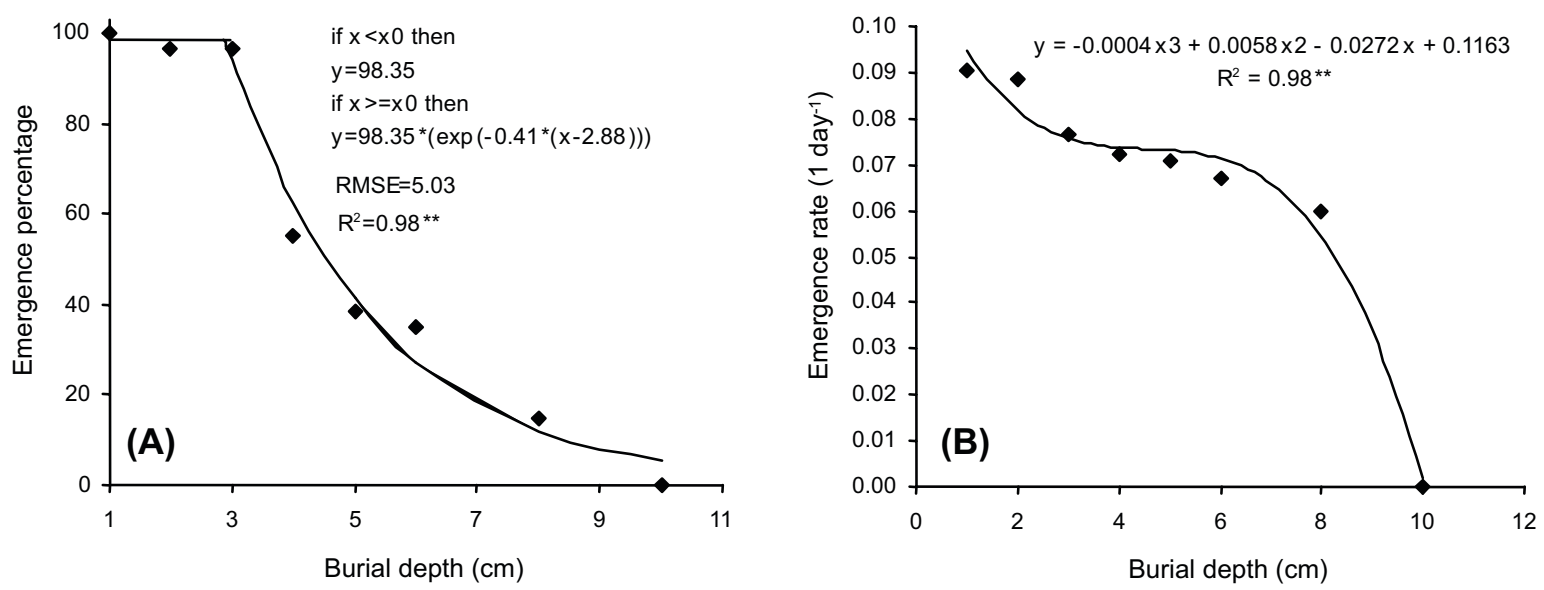

Figure 5 - Relationships between seedling emergence percentage (a) and seedling emergence rate (b) with burial depth in volunteer oilseed rape

Table 3 - Parameter estimates of the hydrothermal time model, describing seed germination of volunteer oilseed rape, at the ranges of temperatures and water potentials. $\mathrm{T}_{\mathrm{b}}$ and $\mathrm{T}_{\mathrm{o}}$ are the base and optimum temperatures; $\psi_{\mathrm{b}(50)}$ is the median base water potential; $\psi_{\mathrm{b}(50) \mathrm{o}}$ is the value of the $\psi_{\mathrm{b}(\mathrm{g})}$ at $\mathrm{T}_{\mathrm{o}} ; \mathrm{k}_{\mathrm{T}}$ is a constant (the slope of the $\psi_{\mathrm{b}(\mathrm{g})}$ versus $\mathrm{T}$ line when $\mathrm{T}>\mathrm{To}$ ); $\mathrm{HTT}_{(50)}$ is the hydrothermal time constant; R2 is the coefficient of determination of the hydrothermal time model

\begin{tabular}{|l|c|c|}
\hline Parameter & Sub-optimal & Supra-optimal \\
\hline $\mathrm{T}_{\mathrm{b}}$ & $3.79 \pm 0.151$ & $3.38 \pm 0.144$ \\
\hline $\mathrm{T}_{\mathrm{o}}$ & - & $26.23 \pm 0.127$ \\
\hline$\psi_{\mathrm{b}(50)}$ & $-1.43 \pm 0.033$ & - \\
\hline$\psi_{\mathrm{b}(50) \mathrm{o}}$ & - & $-1.23 \pm 0.129$ \\
\hline $\mathrm{k}_{\mathrm{T}}$ & - & 0.042 \\
\hline $\mathrm{HTT}_{(50)}$ & $36.21 \pm 1.006$ & $42.93 \pm 6.56$ \\
\hline $\mathrm{R}^{2}$ & 0.94 & 0.96 \\
\hline
\end{tabular}

seeds from soil depths of 8 to $30 \mathrm{~cm}$ (Figure 6). These seeds were dormant and could give rise to volunteers in subsequent years in farmers' fields. Dormancy was first observed at a soil depth of $8 \mathrm{~cm}$, where there were $10 \%$ ungerminated seeds, and increased to approximately $40 \%$ at a soil depth of $30 \mathrm{~cm}$ (Figure 6).

Quantification of seed emergence as influenced by burial depth was performed satisfactorily, and it was revealed that volunteer oilseed rape will not emerge from a burial depth greater than $10 \mathrm{~cm}$. There is a number of reports on oilseed rape emergence as affected by seed depth: Gruber et al. (2010) reported that the emergence rates of oilseed rape were highest at soil depths of $1-5 \mathrm{~cm}$, whereas they were clearly reduced at depths 


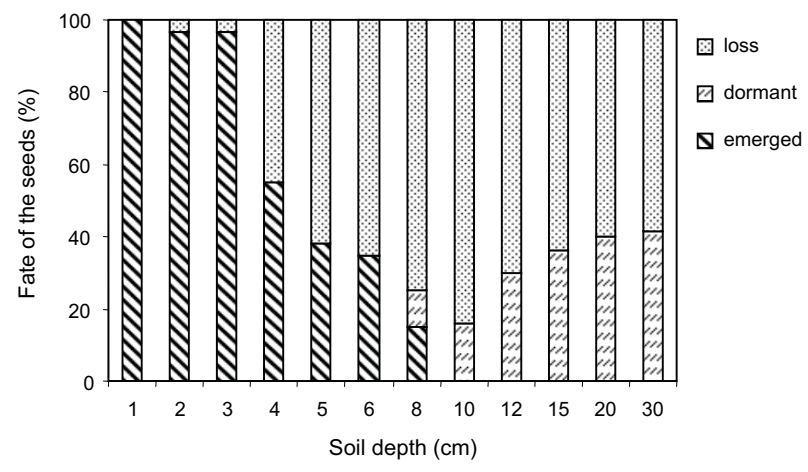

Figure 6 - Fate of oilseed rape seeds at the different soil depths in a pot experiment in Gorgan

of 0 and $7 \mathrm{~cm}$, and emergence was completely inhibited at $12 \mathrm{~cm}$. Colbach et al. (2008) showed that GENESYS can predict oilseed rape emergence as affected by seed depth. In this study, the same results were found for the cultivar and environment.

Overall, the seasonal pattern of seedling emergence and the persistence of buried seeds have been introduced as two important factors determining the success of weed species (Figueroa et al., 2007). It has been indicated that secondary dormancy in oilseed rape seeds is influenced by darkness in combination with osmotic stress, hypoxia and temperature (Pekrun et al., 1997a, b, 1998; Momoh et al., 2002; Gulden et al., 2004). In this study, it was observed that the dormancy level of volunteer oilseed rape increased during spring and early summer (study 1) and was affected by soil depth (study 3). In the present study, there was a dormancy/non-dormancy cycle in which volunteer oilseed rape was not exposed to light for germination and was buried at a soil depth of $30 \mathrm{~cm}$. Therefore, it can be concluded that volunteer oilseed rape exhibits Type 1 non-deep PD (Baskin \& Baskin, 2006), as germinability decreased from spring to summer.

This study employed modelling three subprocesses of the volunteer oilseed rape seed bank to show the life-cycle of volunteer oilseed rape in the soil seed bank. The parameters and relationships estimated can be used in models for soil seed bank dynamics (e.g., GENESYS by Colbach et al., 2001a, b; Sester et al., 2008; ALOMYSYS by Colbach et al., 2006), or they may be used to establish a new model for environmental conditions. These models have been satisfactorily used to study the effects of cropping systems on seed bank dynamics (Sester et al., 2007), germination and emergence, interacting with seed characteristics, tillage and soil climate (Colbach et al., 2006) and gene escape (Colbach et al., 2001a, b). The results of this study will also be useful for future studies of volunteer oilseed rape biology and ecology.

\section{LITERATURE CITED}

ALVARADO, V. Hydrothermal time model of botanical potato seed germination. 2000. $71 \mathrm{f}$. Dissertation (M.S.) University of California, Davis, 2000.

BAIR, N. B. et al. A hydrothermal after-ripening time model for seed dormancy loss in Bromus tectorum L. Seed Sci.

Res., v. 16, n. 1, p. 17-28, 2006.

BASKIN, C. C.; BASKIN, J. M. The natural history of soil seed banks of arable land. Weed Sci., v. 54, n. 3, p. 549-557, 2006.

BATLLA, D.; BENECH-ARNOLD, R. L. Predicting changes in dormancy level in weed seed soil banks: Implications for weed management. Crop Protec., v. 26, n. 1, p. 189-197, 2007.

BEGG, G. S. et al. Modelling the persistence of volunteer oilseed rape (Brassica napus). Ecol. Model., v. 198, n. 1, p. 195-207, 2006.

BENECH-ARNOLD, R. L. et al. Environmental control of dormancy in weed seed banks in soil. Field Crops Res., v. 67, n. 1, p. $105-122,2000$

BENVENUTI, S. Natural weed seed burial: effect of soil texture, rain and seed characteristics. Seed Sci. Res., v. 17, n. 3, p. 211-219, 2007.

BRADFORD, K. J. A water relations analysis of seed germination rates. Plant Physiol., v. 94, n. 2, p. 840-849, 1990.

BRADFORD, K. J. Water relations in seed germination. In: KIGEL, J.; GALILI, G. (Ed.). Seed development and germination. New York: Marcel Dekker, 1995. p. 351-396.

BRADFORD, K. J. Applications of hydrothermal time to quantifying and modeling seed germination and dormancy. Weed Sci., v. 50, n. 2, p. 248-260, 2002.

CHUAH, T. S. et al. Changes in seed bank size and dormancy characteristics of the glyphosate-resistant biotype of goosegrass (Eleusine indica L. Gaertn.). Weed Biol. Manag., v. 4, n. 2, p. 114-121, 2004. 
COLBACH, N. et al. Construction and evaluation of ALOMYSYS modelling the effects of cropping systems on the blackgrass life-cycle: From seedling to seed production. Ecol. Model., v. 201, n. 3, p. 283-300, 2007.

COLBACH, N. et al. GENESYS: a model of the influence of cropping system on gene escape from herbicide tolerant rapeseed crops to rape volunteers. I. Temporal evolution of a population of rapeseed volunteers in a field. Agric. Ecol. Environ., v. 83, n. 3, p. 235-253. 2001a.

COLBACH, N. et al. GENESYS: A model of the influence of cropping system on gene escape from herbicide tolerant rapeseed crops to rape volunteers. II. Genetic exchanges among volunteer and cropped populations in a small region. Agric. Eco. Environ., v. 83, n. 3, p. 255-270, 2001 b.

COLBACH, N.; DEBAEKE, P. Integrating crop management and crop rotation effects into models of weed population dynamics: a review. Weed Sci., v. 46, n. 6, p. 717-728, 1998.

COLBACH, N. et al. AlomySys: Modelling black-grass (Alopecurus myosuroides Huds.) germination and emergence, in interaction with seed characteristics, tillage and soil climate I. Construction. Europ. J. Agron., v. 24, n. 1, p. 95-112, 2006.

COLBACH, N. et al. Modelling the seed bank evolution and emergence of oilseed rape volunteers for managing coexistence of GM and non-GM varieties. Euro. J. Agron., v. 28, n. 1, p. 19-32, 2008.

ELLIS, R. H. et al. The influence of temperature on seed germination rate in grain legumes. J. Exper. Bot., v. 37, n. 10, p. $1503-1515,1986$

FIGUEROA, R. et al. Common Groundsel (Senecio vulgaris) Seed Longevity and Seedling Emergence. Weed Sci., v. 55, n. 3, p. 187-192, 2007.

FRANKE, A. C. et al. Phalaris minor seedbank studies: longevity, seedling emergence and seed production as affected by tillage regime. Weed Res., v. 47, n. 1, p. 73-83, 2007.

GARDARIN, A. et al. Effects of seed depth and soil structure on the emergence of weeds with contrasted seed traits. Weed Res., v. 50, n. 1, p. 91-101, 2010a.

GARDARIN, A. et al. Estimation of key parameters for weed population dynamics models: base temperature and base water potential for germination. Europ. J. Agron., v. 32, n. 2 , p. $162-168$. 2010 b.

GARDARIN, A. et al. Prediction of germination rates of weed species: relationships between germination parameters and species traits. Ecol. Model., v. 222, n. 3, p. 626-636 2011.

Planta Daninha, Viçosa-MG, v. 31, n. 2, p. 267-279, 2013
GONZALEZ-ANDUJAR, J.L.; FERNANDEZQUINTANILLA, C. Modelling the population dynamics of annual ryegrass (Lolium rigidum) under various weed management systems. Crop Protec., v. 23, n. 6, p. 723-729, 2004.

GRUBER, S.; CLAUPEIN, W. Fecundity of volunteer oilseed rape and estimation of potential gene dispersal by a practicerelated model. Agric. Ecol. Environ., v. 119, n. 4, p. 401-408, 2007.

GRUBER, S. et al. Post-harvest gene escape and approaches for minimising it. CAB Reviews: Perspectives in Agriculture, Veterinary Science, Nutrition and Natural Resources 3, No. 015, electronical source: <http:// www.cababstractsplus.org/cabreviews>. 2008.

GRUBER, S. et al. Sleepers in the soil - vertical distribution by tillage and long-term survival of oilseed rape seeds compared with plastic pellets. Europ. J. Agron., v. 33, n. 1, p. $81-88,2010$

GULDEN, R. H. et al. Harvest losses of canola (Brassica napus) cause large seedbank inputs. Weed Sci., v. 51, n. 1, p. $83-86,2003$

GULDEN, R. H. et al. Secondary dormancy, temperature, and burial depth regulate seedbank dynamics in canola.

Weed Sci., v. 52, n. 3, p. 382-388, 2004.

GUMMERSON, R. J. The effect of constant temperature and osmotic potential on the germination of sugar beet. $\mathbf{J}$. Exper. Bot., v. 37, n. 179, p. 729-714, 1986

KEBREAB, E.; MURDOCH, A. J. The effect of water stress on the temperature range for germination of Orobanche aegyptiaca seeds. Seed Sci. Res., v. 10, n. 2, p. 127-133, 2000 .

KNOTT, C. M. Control of volunteer oilseed rape in peas. In: BRIGHTON CROP PROTECTION CONFERENCEWEEDS, 1993, Brighton. Procedings... Brighton: 1993. p. 889-894, 1993.

LAWSON, A. N.; FRIESEN, L. F. Emergence timing of volunteer canola in spring wheat fields in Manitoba.

Weed Sci., v. 54, n. 5, p. 873-882, 2006.

LUTMAN, P. J. W.; LÓPEZ-GRANADOS, F. The persistence of seeds of oilseed rape (Brassica napus). Aspects Appl. Biol., v. 51, n. 2, p. 147-152, 1998.

MARSHALLl, B.; SQUIRE, G. R. Non-linearity in ratetemperature relations of germination in oilseed rape. J. Exper. Bot., v. 47, n. 9, p. 1369-1375, 1996.

MARTINSON, $\mathrm{K}$. et al. An emergence model for wild oat (Avena fatua). Weed Sci., v. 55, n. 6, p. 584-591, 2007. 
MASIN, R. et al. WeedTurf: a predictive model to aid control of annual summer weeds in turf. Weed Sci., v. 53, n. 2 , p. 193-201, 2005.

MASIN, R. et al. Seed longevity and dormancy of four summer annual grass weeds in turf. Weed Res., v. 46, n. 3, p. 362-370, 2006.

MIDDELHOFF, U. et al. GeneTraMP, a spatio-temporal model of the dispersal and persistence of transgenes in feral, volunteer and crop plants of oilseed rape and related species. Ecol. Indic., v. 11, n. 4, p. 974-988, 2011.

MOMOH, E. J. J. et al. Variation in the development of secondary seed dormancy in oilseed rape genotypes under conditions of stress. Weed Res., v. 42, n. 4, p. 446-455, 2002

PEKRUN, C. et al. Germination behavior of dormant oilseed rape seeds in relation to temperature. Weed Res., v. 37, n. 4, p. 419-431, 1997a.

PEKRUN, C. et al. Genotypic variation in the development of secondary dormancy in oilseed rape and its impact on the persistence of volunteer rape. In: BRIGHTON CROP PROTECTION COUNCIL CONFERENCE - WEEDS, 1997, Farnham, Surrey. Proceedings... Farnham, Surrey: British Crop Protection Council, 1997b. p. 243-248.

PEKRUN, C. et al. Cultural control of volunteer oilseed rape (Brassica napus). J. Agric. Sci. v. 130, n. 1, p. 155-163, 1998.

PEKRUN, C. et al. Modelling seedbank dynamics of volunteer oilseed rape (Brassica napus). Agric. Syst., v. 84, n. 1, p. 1-20, 2005.

RITCHIE, J. T.; NESMITH, D. S. Temperature and crop development. In: HANKS, R. J.; RITCHIE, J. T. (Ed.) Modeling Plant and Soil Systems. Agron. Monogr., v. 31, n. 1, p. 5-29, 1991.

ROWSE, H. R.; FINCH-SAVAG, E. Hydrothermal threshold models can describe the germination response of carrot (Daucus carota) and onion (Allium cepa) seed populations across both sub- and supra-optimal temperatures. New Phytol., v. 158, n. 1, p. 101-108, 2003.

SAS Institute. The SAS system for Microsoft Windows Release 8.01. Cary: 2000
SCHLINK, S. Ecology of germination and dormancy in oilseed rape (Brassica napus L.) and their importance for the survival of the seeds in soil. 1994. $193 \mathrm{f}$. Dissertation (Master in Botany) - Faculty of Biology, University of Berlin, Berlin, 1994.

SCHUTTE, B. J. et al. A hydrothermal Seedling Emergence Model for Giant Ragweed (Ambrosia trifida). Weed Sci., v. 56, n. 5 , p. $555-560,2008$

SESTER, M. et al. Modelling the effects of cropping systems on the seed bank dynamics and the emergence of weed beet.

Ecol. Model., v. 204, n. 1, p. 47-58, 2007.

SESTER, M. et al. GeneSys-Beet: A model of the effects of cropping systems on gene flow between sugar beet and weed beet. Field Crops Res., v. 107, n. 2, p. 245-256, 2008 .

SIMARD, M. J. et al. The frequency and persistence of volunteer Canola (Brassica napus) in Québec cropping systems. Weed Technol., v. 16, n. 4, p. 433-439, 2002.

SOLTANI, A. et al. Genetic variation for and interrelationships among seed vigor traits in wheat from the Caspian Sea Coast of Iran. Seed Sci. Technol., v. 29, n. 4, p. 653-662, 2001.

SOLTANI, A. et al. Germination, seed reserve utilization and seedling growth of chickpea as affected by salinity and seed size. Seed Sci. Technol., v. 30, n. 1, p. 51-60, 2002.

SOLTANI, A. et al. Modeling seedling emergence in chickpea as influenced by temperature and sowing depth. Agric. For. Meterol., v. 138, n. 2, p. 156-167, 2006.

SOLTANI, E. et al. Modeling seed aging effects on the response of germination to temperature in wheat. Seed Sci. Biotechnol., v. 2, n. 1, p. 32-36, 2008.

SQUIRE, G. R. Temperature and heterogeneity of emergence time in oilseed rape. Ann. Appl. Biol., v. 135, n. 4, p. 439-447, 1999.

THOMAS, A. G., LEESON, J. Y. Persistence of volunteer wheat and canola using weeds survey data [abstract]. In: EXPERT COMMTTEE ON WEEDS; 1999, Ottawa. Proceedings... Ottawa: Sainte-Anne-de-Bellevue, QC, Canada: Expert Committee on Weeds, 1999. p. 94. 